Arab Univ. J. Agric. Sci., Ain Shams Univ., Cairo, Egypt 28(2), 673-684, 2020

Website: http://ajs.journals.ekb.eg

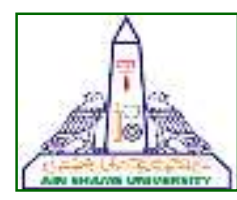

\title{
ASSESSMENT AND SPATIAL ANALYSIS OF SENSITIVITY TO DESERTIFICATION IN WADI EL NATRUN, NORTHWESTERN EGYPT USING MEDLAUS MODEL
}

\author{
Hoda Nour-Eldin ${ }^{\star}$, Sheta ${ }^{2}$ A.S., Shalaby ${ }^{1}$ A., Abd-Elwahed ${ }^{2}$ M.S. \\ and El-Shinawy ${ }^{3}$ M.Z.
}

1- Land Use Dept., National Authority for Remote Sensing and Space Sci., (NARSS), Cairo, Egypt

2- Soil Science Dept., Fac. of Agric., Ain Shams Univ., P.O. Box 68, Hadayek Shoubra 11241, Cairo, Egypt

3- Horticulture Dept., Fac. of Agric., Ain Shams Univ., P.O. Box 68, Hadayek Shoubra 11241, Cairo, Egypt

${ }^{*}$ Corresponding author: hoda.noureldin2008@gmail.com

Received 21 May, 2020

Accepted 16 August, 2020

\section{ABSTRACT}

Desertification processes reduce the productivity of soil and as a result affect food stocks. The main objective of this study is integrating remote sensing data and a geographic information system (GIS) to evaluate the environmental sensitivity to desertification in Wadi El Natrun, Egypt based on the Mediterranean Desertification and Land Use (MEDALUS) approach. The collected soil data; from description of represented soil profiles and analysis of soil samples, in addition to climate, plant cover, and management data were considered for assessing the sensitivity of desertification. The obtained results showed that $10.4 \%$ of Wadi El Natrun area is considered as a severe sensitive area to desertification owing to alkalinity and salinity, while the moderate sensitive class occupies approximately $10.93 \%$ of the study area. The low sensitive area exhibits $76.3 \%$. This area is described by high soil quality because the study area is one of the new development areas which is not affected by the factors of desertification.

Keywords: Desertification, MEDALUS, Wadi El-Natrun, GIS, Remote sensing

\section{INTRODUCTION}

Land degradation is a global environmental is sue, given the various negative impact for socioeconomic and ecological implications. According to the United Nations Convention to Combat Desertification (UNCCD), Land degradation leads to reduced production capacity in addition to soil erosion, physical/chemical/biological /economic land deterioration, and long-term loss (or degradation) of vegetation. When a severe deterioration in drought areas called the process of desertification i.e. arid, dry sub-humid and, semi-arid areas (UNCCD, 1994).

Desertification affects about one billion populations in about one hundred countries (Adger et al 2000). It is mainly as a result of an important set of processes, which are active in arid and a semi-arid environment, where the amount of water is the main determining factor for land use performance in the ecosystems (Gad and Shalaby, 2010). The interaction and interference between several factors such as land cover, climate, physical human activities and change in natural and land use caused in the increase of desertification phenomenon (Thomas, 1997 and UNCCD, 2000). Human is one of the most factors which resulted in an increase of the phenomenon of desertification (Herrmann and Hutchinson, 2005). In the last decades, several methods and approaches have been advanced to classify areas of land degradation such as spectral biophysical indicators (Lamchin et al 2016). To characterize the desertification process in an easy and a comprehensive way, specific indicators can be used by taking into consideration qualitative and quantitative methods (Lamqadem et al 2018 and Gad, 2020). The MEDALUS model has been used 
in different Mediterranean regions at local, national, and regional scales. Kosmas et al (1999) developed the MEDALUS methodology for identifying the most areas which are sensitive to desertification at different scales (Luca and Sofia, 2011). Four indicators have been used in the MEDALUS model to assess the desertification index which are vegetation quality, climate quality, management quality, and soil quality. Many researches used the MEDALUS model to assess the desertification in the Mediterranean region with precise satisfactory results (Basso et al 2000 and Eun et al 2019).

Wadi El Natrun has always been confined as a possible area for reclamation because of its good location and has groundwater appropriate to irrigation. The source of this water is the streams of the Nile River, due to its closeness and low level (El-Maghraby, 1990). Wadi El Natrun is considered one of the most important depressions in the Western Desert of Egypt, which is famous for its reclaiming new lands. Agriculture in Wadi El Natroun depended on groundwater with spraying and drip method, field crops and orchards have been cultivated in the newly reclaimed land. Thus, the existence of irrigation water as ground water of suitable quality, the existence of natural freshwater springs and availability of water in the sandy layers above the shallow water table southwest of the Depression are the main reasons for the importance of Wadi ElNatrun (Abd El-Ghani et al 2015).

The main objective of the current work is to employ geospatial analyses for assessing and mapping the environmentally sensitive areas (ESAs) to desertification in the area of Wadi El Natrun, North West Coast of Egypt using the MEDALUS multi-factor approach based on both general and local knowledge of the environmental processes acting.

\section{MATERIALS AND METHODS}

\section{Study Area and satellite data}

The study area includes Wadi El Natrun area and the surrounding desert fringes. It is located in Beheira Governorate at about $110 \mathrm{~km}$ northwest from Cairo between longitudes, $30^{\circ} 02^{\prime}$ to $30^{\circ} 29^{\prime} \mathrm{E}$ and latitudes, $30^{\circ} 16^{\prime}$ to $30^{\circ} 32^{\prime} \mathrm{N}$. The area is about $4748 \mathrm{Km}^{2}$, extended in a NW-SE direction and $23 \mathrm{~m}$ below sea level (bsl).

Landsat 8 (OLI) satellite image, acquired in 2018 (Fig. 1) and ASTERDEM satellite data of the investigated area, were used in this study (https:// earthexplorer.usgs.gov/). ENVI (5.3) software was used for image processing, while ArcGIS (10.4.1) was used for modeling and mapping the thematic layers. ASTERDEM data was used to extract the DEM of the investigated area (Fig. 2). Landsat-TM images were used for preparing the physiographic map (Wulder et al 2008), thus they were used for allocating 121 soil profiles representing different physiographic units. Soil profiles were dug down in the field and morphologically described and 332 soil samples were collected for analysis based on morphological features (Fig. 1). The samples were analyzed for physical and chemical characteristics.

\section{Desertification sensitivity analysis}

There are four thematic indicators used for quantifying the environmental quality including; land management, soil, vegetation, and climate that were used in modeling the sensitivity to desertification (Kosmas et al 1999 and Sepehr et al 2007). The model includes the following formula: DSI= (SQI*VQI*CQI*MQI) ${ }^{1 / 4}$. Where DSI is Desertification Sensitivity Index, SQI is the Soil Quality Index, VQI is the Vegetation Quality Index, CQI is the Climate Quality Index and MQI is the Management Quality Index. The soil indicator was calculated using seven parameters including; soil texture, slope gradient, soil depth, soil drainage condition, soil electric conductivity and soil Calcium carbonates content (Le Bissonnais, 1996 and Mohamed, 2013). Two additional variables were taken into account in soil quality index calculation i.e. salinity and alkalinity. The SQI indicator was obtained using the geometric mean of the score sub-indicators' values, with the formula: SQI = (Soil depth * Slope * Texture * Drainage * Calcium carbonates ${ }^{*}$ Soil salinity and Alkalinity) ${ }^{1 / 7}$ (Kosmas et al 1999).

The vegetation indicator was assessed based on three parameters; plant cover density, drought resistance and erosion protection. The Plant cover was computed by deriving the Normalized Difference Vegetation Index (NDVI) retrieved from the Landsat image of the investigated area. The Vegetation Quality index (VQI) was estimated using the following equation: VQI= (Drought resistance* Erosion protection* Plant cover) ${ }^{1 / 3}$ (Kosmas et al 1999). The management indicator was calculated based on Grazing intensity and land use. The Management Quality Index (MQI) was estimated using the next equation: MQI= (Land use * Grazing intensity $)^{1 / 2}$. 


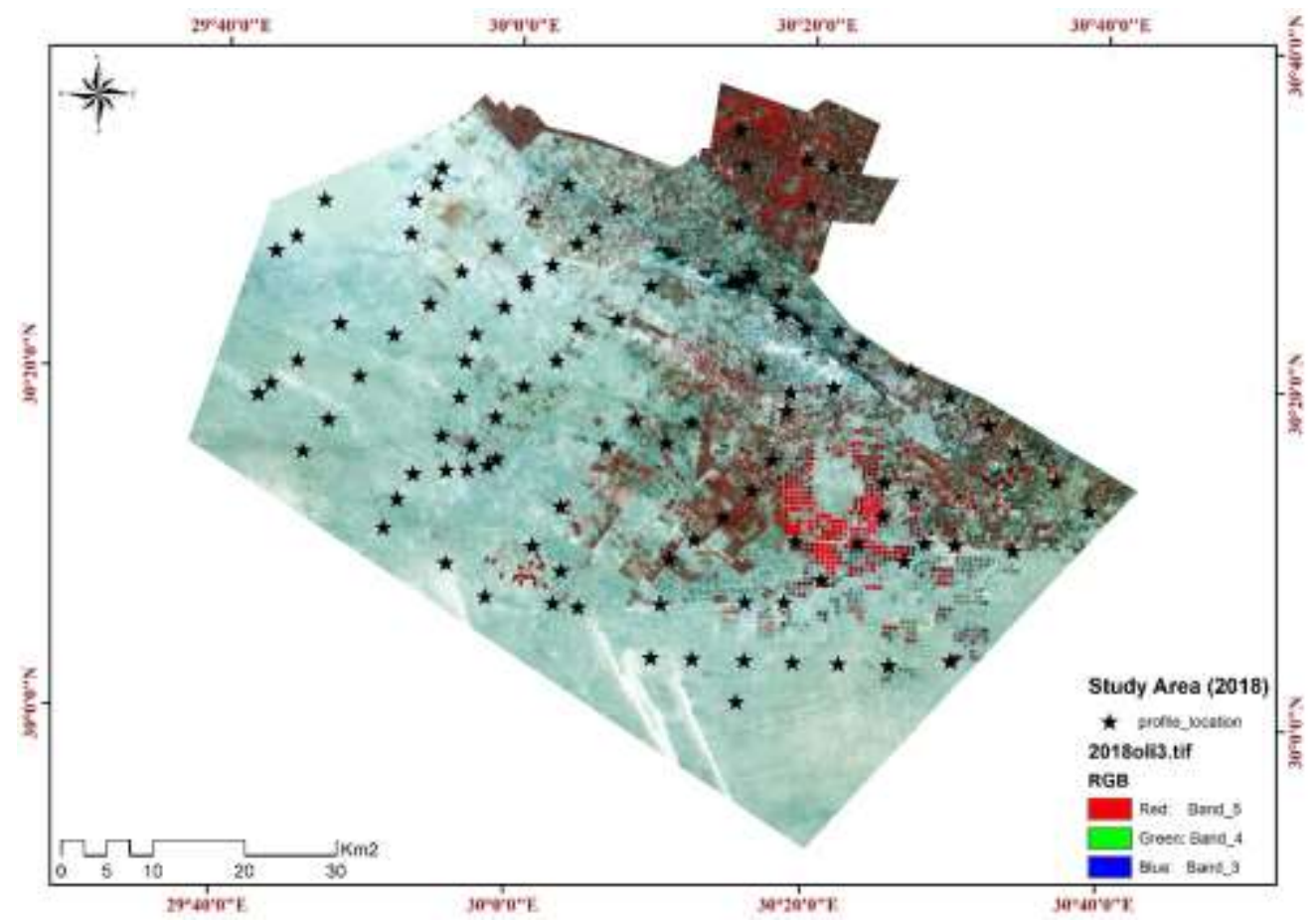

Fig. 1. Wadi El- Natrun Landsat 8(OLI) image 2018 and the distribution of soil samples

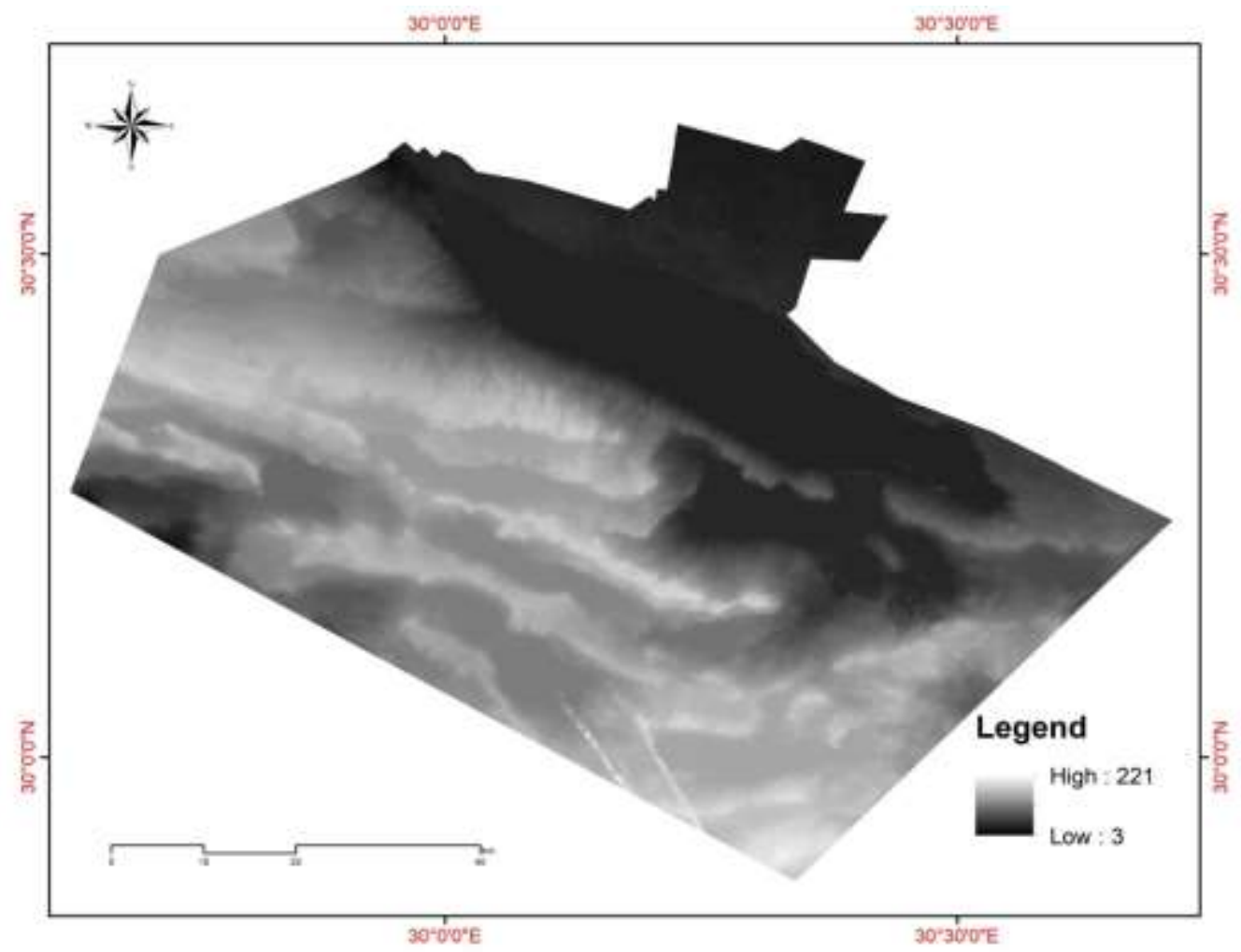

Fig. 2. Digital elevation model (DEM) of the study area 
The climate indicator was calculated based on annual rainfall $(\mathrm{R})$; wind speed $(\mathrm{W})$ and slope aspect (Sa). The different classes of all the indicator parameters and weights are shown in details at Kosmas et al (1999). The slope aspect was derived from ASTERDEM satellite image and calculated using the aspect function of ArcMap 10.4.1. The climate quality index (CQI) was acquired by combining the revealed parameters using the following formula: CQI= (Rainfall * wind speed* Slope aspect $\left.^{\star}\right)^{1 / 3}$.

Finally, the Desertification sensitivity index (DSI) was calculated from the four quality indicators using the following equation: $\mathbf{D S I}=\left(\mathbf{C Q I}{ }^{*} \mathbf{S Q I}\right.$ * VQI * $M Q I)^{1 / 4}$. According to the value of the DSA index, The quality indicators and the DSI index were mapped using Inverse Distance Weighting (IDW) interpolation method in ArcGIS 10.4.1 software.

\section{RESULTS AND DISCUSSION}

\section{Soil physiographical units}

The results of physiographic units extraction indicated that within Wadi EI Natrun area there are major landforms, namely, streams, sandy plain, ridges, enter ridges, depressions, and terraces (Fig. 3). The streams are characterized as dry wadis ephemeral stream channel, especially in semiarid regions which only moves water in response to intense, infrequent precipitation as reported by Schoeneberger and Wysocki (2005). Sandy plain is formed from sand sheet and a rather flat sandy area without any apparent surface structure. Terraces (high, low and medium) are structures of varying size and shape consisting of a flat section, which is cultivated, and an almost vertical riser protected by a stone wall. Rock out crops is a visible exposure of bedrock or ancient superficial deposits on the surface of the earth as shown in Fig. 3.

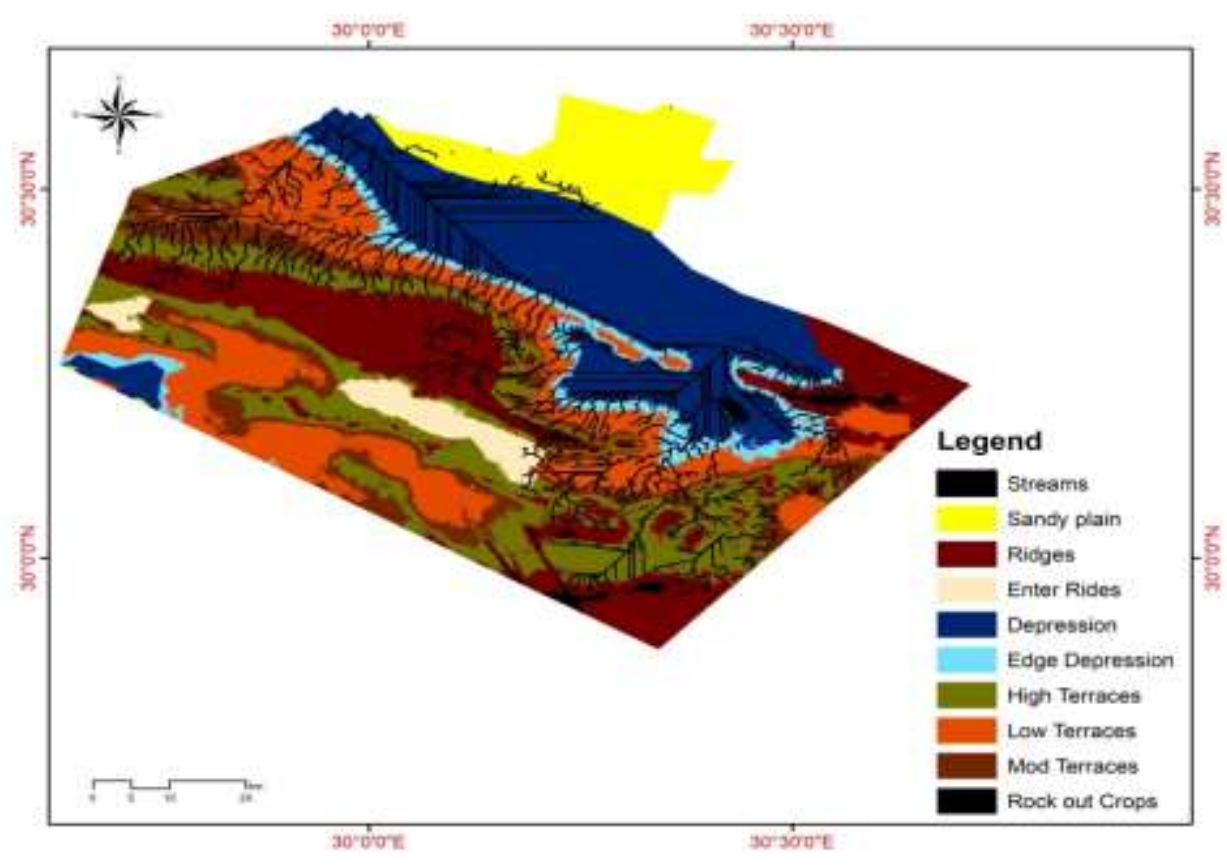

Fig. 3. The physiographic units of the study area.

Soil quality index: Data in Table (1) represent some chemical and physical properties of representative soil profiles of the studied physiographic units. It indicated that most of the studied soil samples are sandy textured soil with low silt and clay, very low in calcium carbonate content and variable soil salinity and alkalinity levels. The results of soil quality indicators and soil quality evaluation are presented in Fig. (4) and Table (2). It indicated that $91.6 \%\left(4349.84 \mathrm{Km}^{2}\right)$ of the studied area is classified as "high soil quality". They occupy areas where slopes are strong and are dominated by a fine texture which promote good drainage. The moderate 
soil quality class occupied about $199.45 \mathrm{Km}^{2}$ representing $4.2 \%$ of the total area. Moreover, the soils of low qualities, which are very vulnerable to degradation, are about $3.02 \%\left(143.41 \mathrm{Km}^{2}\right)$ of the total area. The low soil quality areas are distributed in small patches in the middle of the study location. The limiting factors of soil quality are salinization and soil alkalinity.

Table 1. Some Physical and Chemical properties of representative soil profiles

\begin{tabular}{|c|c|c|c|c|c|c|c|}
\hline Prof. No & Depth & Texture & \%clay \&Silt & $\mathrm{pH}$ & $\mathrm{EC} \mathrm{dS} / \mathrm{m}$ & $\mathrm{CaCO}_{3}$ & Physiographic unit \\
\hline \multirow[t]{2}{*}{16} & $0-30$ & Sand & 1.15 & 8.59 & 0.12 & 0.2 & Mod Terraces \\
\hline & $30-60$ & Sand & 2.68 & 8.84 & 0.80 & 0.2 & \\
\hline \multirow[t]{3}{*}{22} & $0-30$ & Sand & 4.18 & 8.31 & 0.86 & 0.1 & Low Terraces \\
\hline & $30-60$ & Sand & 3.93 & 8.87 & 1.34 & 0.2 & \\
\hline & $60-150$ & Sand & 4.93 & 8.48 & 5.64 & 0.3 & \\
\hline \multirow[t]{3}{*}{48} & $0-30$ & Sand & 1.5 & 8.5 & 1.10 & 0.1 & Edge Depression \\
\hline & $30-60$ & Sand & 2.5 & 8.51 & 0.70 & 0 & \\
\hline & $60-150$ & Sand & 2.3 & 8.82 & 0.70 & 0 & \\
\hline \multirow[t]{3}{*}{51} & $0-30$ & Sand & 1.7 & 7.19 & 6.35 & 0.4 & Enter Ridges \\
\hline & $30-60$ & Sand & 2.4 & 8.22 & 1.10 & 0.6 & \\
\hline & $60-150$ & Sand & 2.6 & 8.22 & 4.10 & 0.7 & \\
\hline \multirow[t]{3}{*}{68} & $0-30$ & Sand & 2.71 & 7.28 & 5.87 & 0.2 & Depression \\
\hline & $30-60$ & Sand & 2.22 & 7.72 & 5.70 & 0.4 & \\
\hline & $60-120$ & Sand & 2.33 & 7.85 & 3.60 & 0.4 & \\
\hline \multirow[t]{3}{*}{84} & $0-30$ & Sand & 1.5 & 8.44 & 2.10 & 0.1 & Ridges \\
\hline & $30-60$ & Sand & 1.15 & 8.24 & 0.90 & 0.1 & \\
\hline & $60-150$ & Sand & 1.35 & 8.15 & 1.20 & 0.1 & \\
\hline \multirow[t]{3}{*}{94} & $0-30$ & Sand & 2.19 & 7.43 & 1.3 & 0.2 & Sandy Plain \\
\hline & $30-60$ & Sand & 2.16 & 7.63 & 0.69 & 0.1 & \\
\hline & $60-150$ & Sand & 2.26 & 7.74 & 0.49 & 0.1 & \\
\hline \multirow[t]{2}{*}{115} & $0-30$ & Sand & 1.6 & 8.35 & 1.18 & 0.1 & High Terraces \\
\hline & $30-60$ & Sand & 1.71 & 8.24 & 0.97 & 0.1 & \\
\hline \multirow[t]{2}{*}{121} & $0-30$ & Sand & 0.4 & 8.46 & 1.80 & 0.1 & Rock out Crops \\
\hline & $30-120$ & Sand & 0.62 & 8.20 & 1.50 & 0.1 & \\
\hline
\end{tabular}



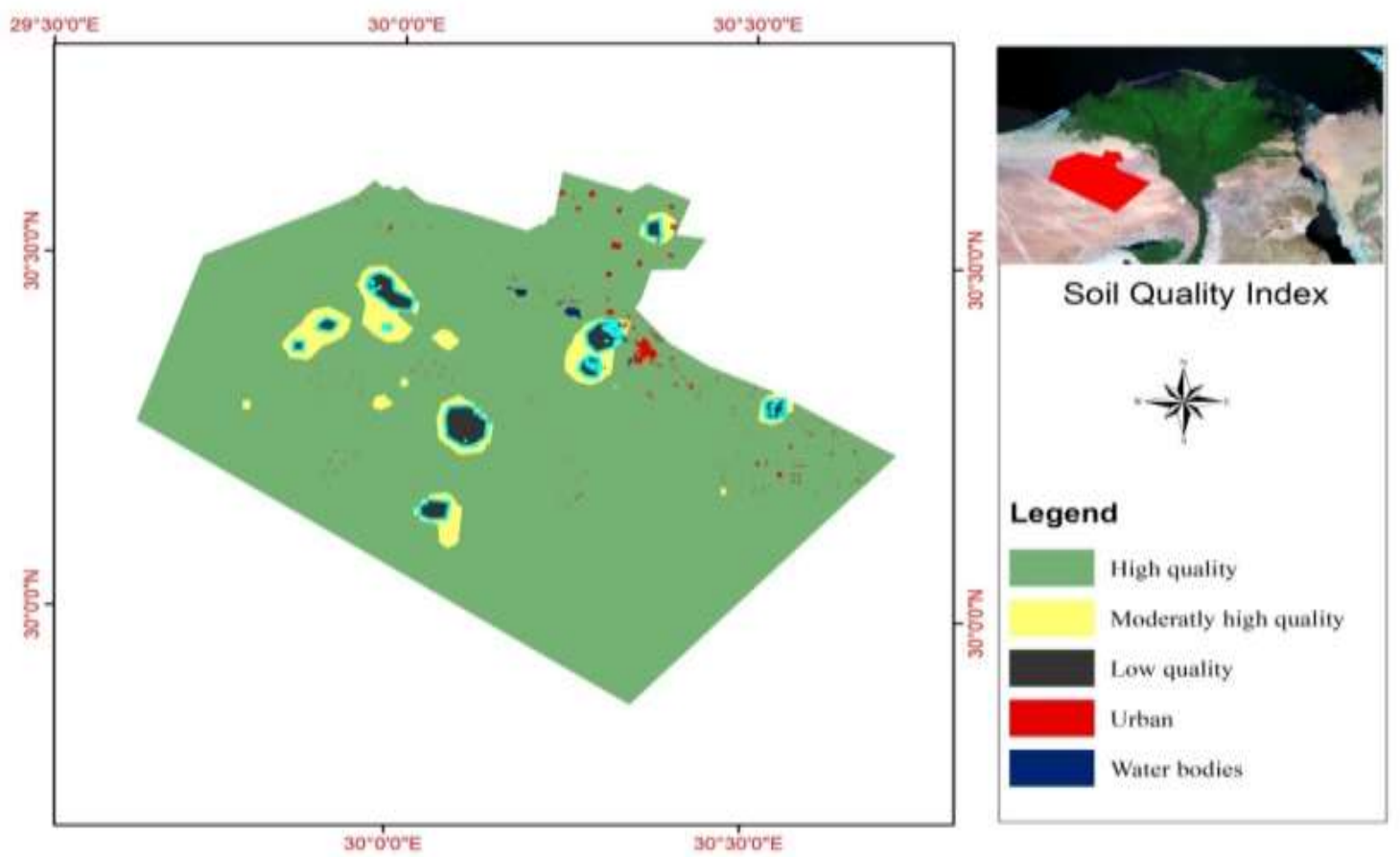

Fig. 4. Classes of soil quality index

Table 2. Soil quality classes in the studied area

\begin{tabular}{|l|c|c|c|}
\hline \multicolumn{1}{|c|}{ SQL class } & Score & $\begin{array}{c}\text { Area } \\
\%\end{array}$ & $\begin{array}{c}\text { Area } \\
\text { (Km2) }\end{array}$ \\
\hline High quality & $<1.2$ & 91.6 & 4349.84 \\
Moderate quality & $1.2-1.25$ & 4.2 & 199.45 \\
Low quality & $>1.5$ & 3.02 & 143.41 \\
$\begin{array}{l}\text { Urban and water } \\
\text { bodies }\end{array}$ & - & 1.2 & 56.98 \\
\hline
\end{tabular}

Vegetation quality index: VQI is an important factor for evaluating the degree of desertification sensitivity. The obtained data revealed that the areas characterized by moderate vegetation quality index occupied an area of about $1.6 \%$ of the investigated area $\left(75.98 \mathrm{~km}^{2}\right)$. About $45 \%$ of the total area was characterized by low vegetation quality index, as shown in Table 3 and Fig. 5. The decrease in vegetation quality index was due to the non-existence of forests and drought resistance crops in the study area.
Table 3. Vegetation quality classes in the studied area

\begin{tabular}{|l|c|c|c|}
\hline \multicolumn{1}{|c|}{ VQL class } & Score & $\begin{array}{c}\text { Area } \\
\%\end{array}$ & $\begin{array}{c}\text { Area } \\
\text { (Km2) }\end{array}$ \\
\hline Moderate quality & $1.2-1.4$ & 1.6 & 75.98 \\
Low quality & $>1.4$ & 45.8 & 2174.92 \\
$\begin{array}{l}\text { Bare land } \\
\begin{array}{l}\text { Urban and water } \\
\text { bodies }\end{array}\end{array}$ & - & 51.4 & 2440.85 \\
\hline
\end{tabular}

Management quality index: MQI contained within grazing intensity and land use, which were essential factors controlling the desertification phenomena. The results in Fig. (6) and Table (4) indicate that about $46.4 \%$ of the total area is suffering from mismanagement of land resources and over-grazing. The areas of moderate quality index represent about $44.1 \%$ of the total area while $8.2 \%$ of the total area is characterized by a high-quality index. These results could be returned to that most of the study area is a non vegetated desert and management plans were not used. 


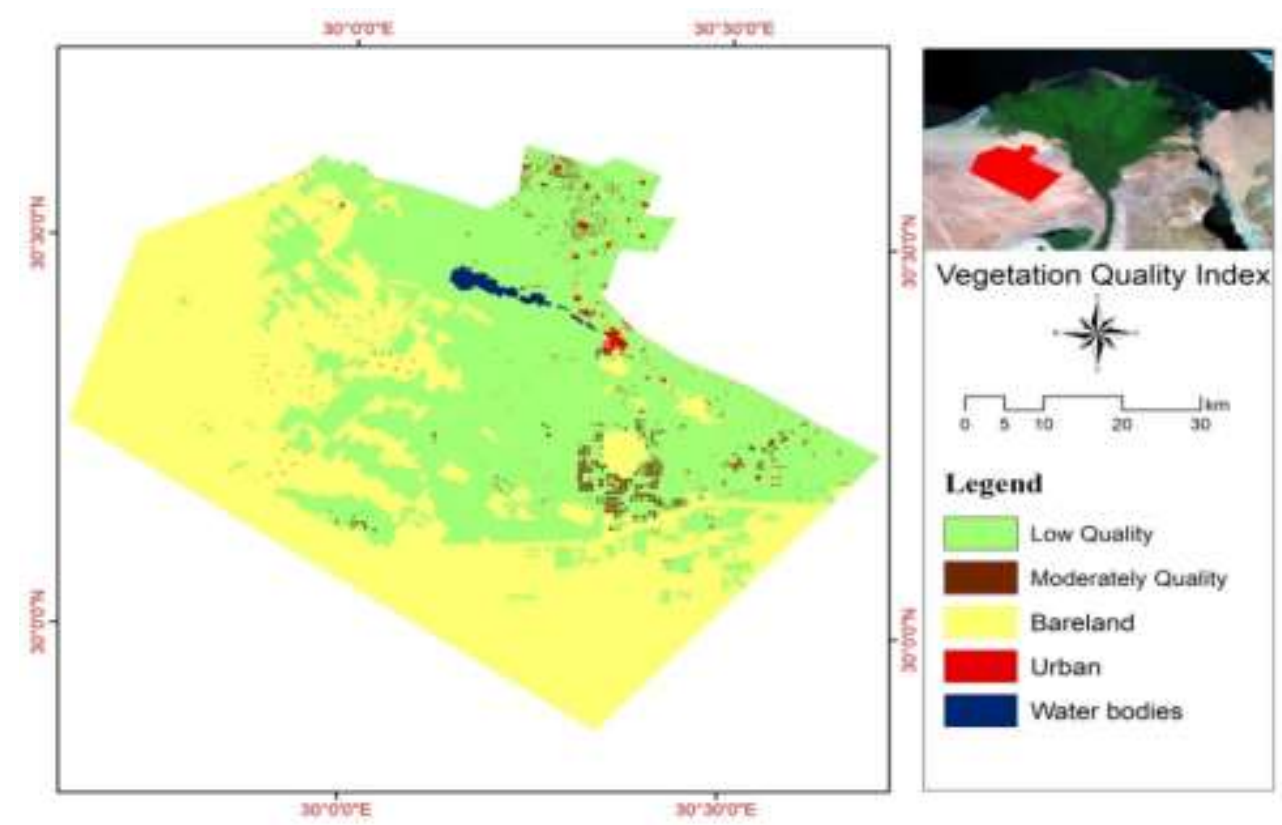

Fig. 5. Vegetation quality index classes of the studied area

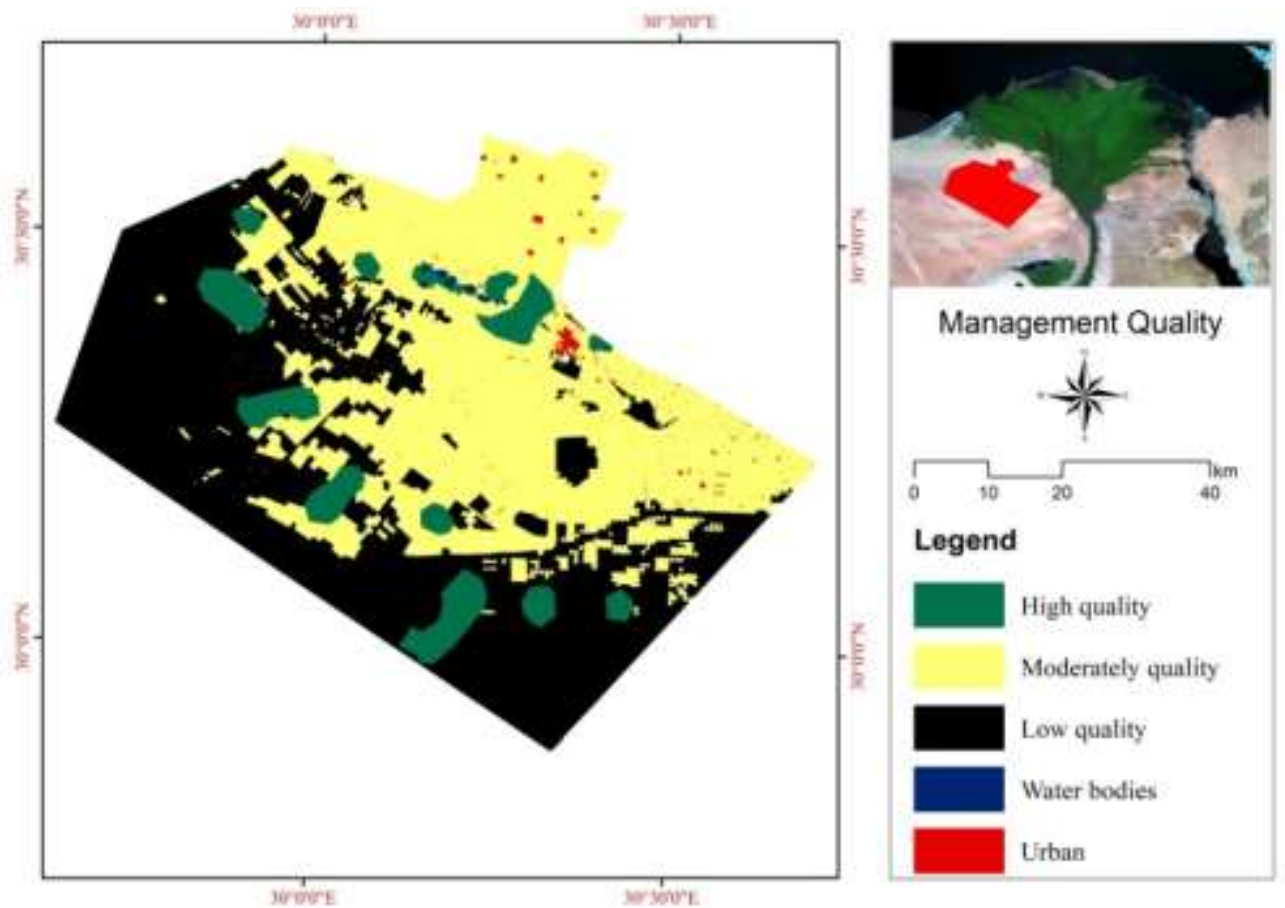

Fig. 6. Classes of management quality index 
Table 4. Management quality classes in the studied area

\begin{tabular}{|l|l|c|c|}
\hline \multicolumn{1}{|c|}{ MQL class } & Score & $\begin{array}{c}\text { Area } \\
\%\end{array}$ & $\begin{array}{c}\text { Area } \\
\text { (Km2) }\end{array}$ \\
\hline High quality & $1-1.3$ & 8.2 & 389.40 \\
Moderate quality & $1.3-1.5$ & 44.1 & 2094.19 \\
Low quality & $>1.5$ & 46.5 & 2208.16 \\
$\begin{array}{l}\text { Urban and water } \\
\text { bodies }\end{array}$ & - & 1.2 & 61.73 \\
\hline
\end{tabular}

Climate quality index: Meteorological data, average of 10 years between 2008-2018 were recorded in Table (5). Data revealed that Wadi El Natrun area is characterized by an extremely arid region. The mean annual wind speed, temperature and rainfall are $3.2 \mathrm{Km} / \mathrm{h}, 16.4^{\circ} \mathrm{C}$, and $26.62 \mathrm{~mm}$, respectively.

The rainfall, aspect and wind speed are the main climatic attributes that contribute to the desertification processes. The result illustrated $37.8 \%$ of the total area characterized by a moderately climatic index (arid). It occupies an area of about $1870.77 \mathrm{~km}^{2}$ as shown in Table 6 and Fig. 7. However, the area which represented $61.3 \%$ is characterized by semiarid conditions. Arid areas are characterized by high elevation thus receiving rainfall which then accumulated in the low lands that are classified as semi-arid areas.

Table 5. The climatological data of the study area

\begin{tabular}{|c|c|c|c|c|c|c|}
\hline \multirow{2}{*}{ Month } & \multicolumn{3}{|c|}{ Average temperature ${ }^{\circ} \mathrm{C}$} & \multirow{2}{*}{$\begin{array}{l}\text { Rainfall } \\
(\mathrm{mm}) \text { total }\end{array}$} & \multirow{2}{*}{$\begin{array}{c}\text { Relative } \\
\text { humidity } \% \\
\end{array}$} & \multirow{2}{*}{$\begin{array}{c}\text { Wind } \\
\text { velocity } \mathrm{km} / \mathrm{h}\end{array}$} \\
\hline & Max. ${ }^{\circ} \mathbf{C}$ & Min. ${ }^{\circ} \mathbf{C}$ & Mean & & & \\
\hline \multirow{6}{*}{$\begin{array}{c}\text { Jan. } \\
\text { Feb. } \\
\text { Mar. } \\
\text { Apr. } \\
\text { May. } \\
\text { Jun. } \\
\text { Jul. }\end{array}$} & 18.4 & 9.7 & 13.4 & 4.20 & 64.6 & 3.2 \\
\hline & 19.9 & 9.9 & 14.3 & 6.20 & 61.4 & 3.2 \\
\hline & 22.6 & 11.3 & 16.3 & 5.90 & 58.1 & 3.3 \\
\hline & 26.2 & 13.7 & 19.4 & 0.60 & 54.1 & 3.2 \\
\hline & 29.2 & 16.8 & 22.5 & 0.30 & 52.6 & 3.2 \\
\hline & 32.6 & 20.4 & 26.0 & 0.00 & 53.8 & 3.4 \\
\hline \multirow{6}{*}{$\begin{array}{c}\text { Aug. } \\
\text { Sep. } \\
\text { Oct. } \\
\text { Nov. } \\
\text { Dec }\end{array}$} & 33.6 & 22.2 & 27.4 & 0.00 & 57.8 & 3.5 \\
\hline & 34.0 & 23.1 & 27.9 & 0.00 & 58.5 & 3.2 \\
\hline & 32.2 & 21.9 & 26.3 & 0.03 & 58.9 & 3.1 \\
\hline & 28.7 & 19.4 & 23.3 & 0.19 & 60.8 & 3.0 \\
\hline & 24.1 & & 19.3 & 2.00 & 64.7 & 2.8 \\
\hline & 19.9 & 12.0 & 15.3 & 7.20 & 65.8 & 3.2 \\
\hline Mean & & & 16.4 & & 59.2 & 3.2 \\
\hline Total & & & & 26.62 & & \\
\hline
\end{tabular}

Table 6. Climate quality classes of the studied area

\begin{tabular}{|l|c|c|c|}
\hline \multicolumn{1}{|c|}{ CQL class } & Score & $\begin{array}{c}\text { Area } \\
\%\end{array}$ & $\begin{array}{c}\text { Area } \\
\text { (Km2) }\end{array}$ \\
\hline $\begin{array}{l}\text { Semi - arid } \\
\text { Arid }\end{array}$ & $1-1.3$ & 61.3 & 2910.97 \\
$\begin{array}{l}\text { Urban and water } \\
\text { bodies }\end{array}$ & $-3-1.5$ & 37.5 & 1780.77 \\
\hline
\end{tabular}

\section{Desertification-sensitive spatial modeling}

The integration of soil parameters, climate conditions, vegetation cover, management, and soil quality were considered to derive the model process. There are four different degrees of desertification recorded in the study area; low, moderate, sensitive and very sensitive as shown in Table 7 and Fig. 8. The major part of the study area was covered by indicated low sensitive areas amounting 3623.28 $\mathrm{km}^{2}(76 \%)$ of the studied area except some scattered areas. These areas are characterized by the 


\section{Assessment and Spatial Analysis of Sensitivity to Desertification in Wadi EI Natrun, Northwestern Egypt using MEDLAUS model}

presence of dense crops and orchards, which reduces soil erosion, in addition to a part of these areas is not cultivated and characterized by high soil quality. However, the very sensitive areas were observed as small patches in different parts of the study area particularly the central zone; amounting $55.56 \mathrm{~km}^{2}(1.17 \%)$. The total recorded areas of moderately sensitive and sensitive classes were nearly the same levels; $519 \mathrm{~km}^{2}$ and $493 \mathrm{~km}^{2}$, respectively. The high sensitivity is attributed to low soil quality, topographic condition, land use, as well as climate condition.

The DSI map showed that there is a spatial leveling in the desertification risk within different sites since the very sensitive areas are located in the middle of the region surrounded by the sensitive and the moderately sensitive areas, respectively. This indicates the negative impact of very sensitive areas on the surrounded lands.

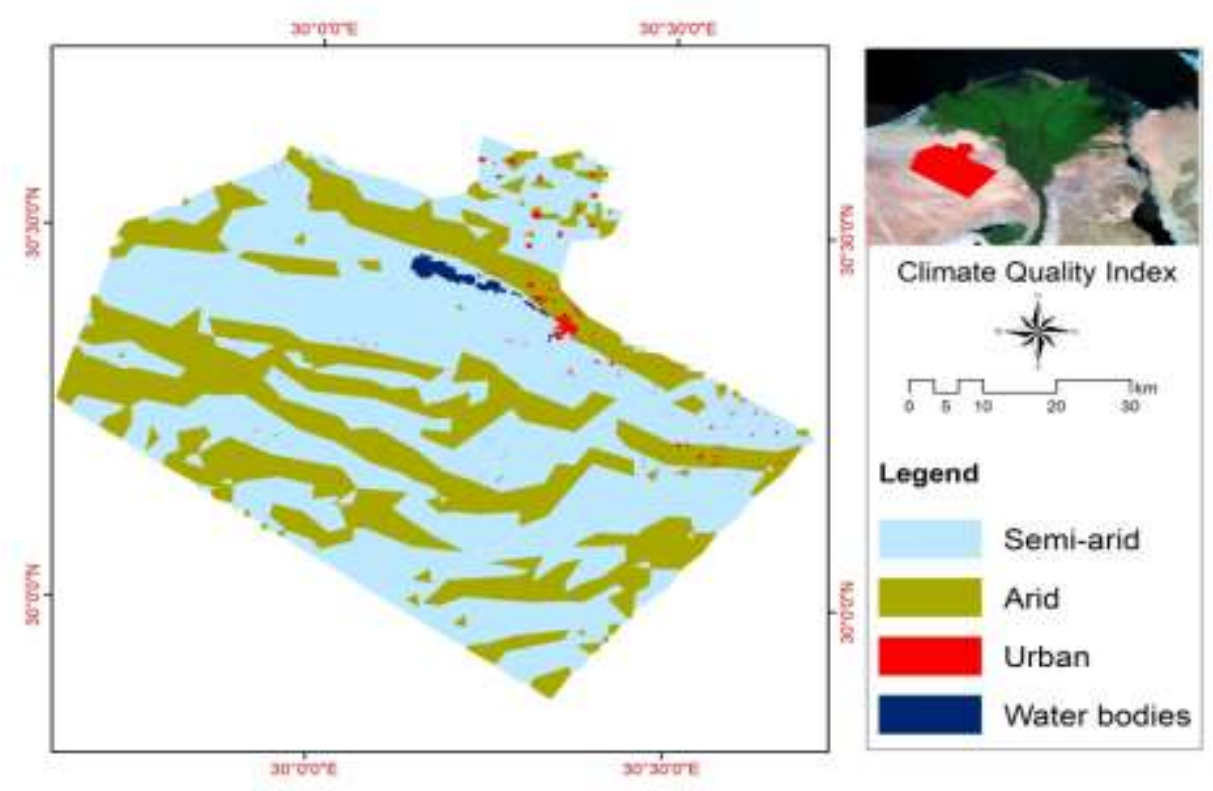

Fig. 7. Classes of the climate quality index

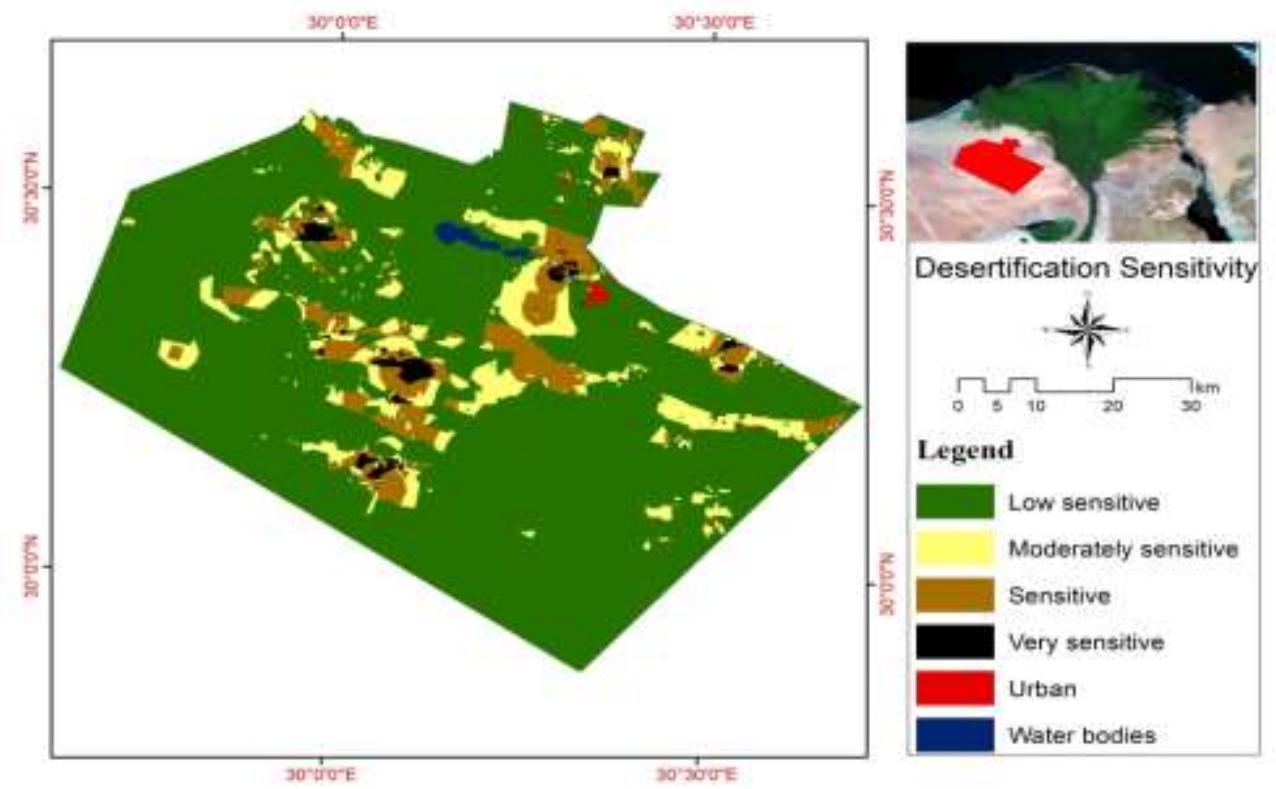

Fig. 8. Desertification sensitivity map of the study area. 
Table 7. Desertification sensitivity classes of the studied area

\begin{tabular}{|c|c|c|c|}
\hline DSI class & Score & Area \% & $\begin{array}{l}\text { Area } \\
\left(\mathrm{Km}^{2}\right)\end{array}$ \\
\hline Low sensitive areas & $1.2-1.3$ & 76.3 & 3623.28 \\
\hline $\begin{array}{l}\text { Moderately sensitive } \\
\text { areas }\end{array}$ & $1.3-1.4$ & 10.93 & 519.04 \\
\hline Sensitive areas & $1.4-1.6$ & 10.4 & 493.87 \\
\hline Very sensitive areas & $>1.6$ & 1.17 & 55.56 \\
\hline $\begin{array}{l}\text { Urban and water } \\
\text { bodies }\end{array}$ & - & 1.2 & 56.98 \\
\hline
\end{tabular}

\section{CONCLUSIONS}

The study area represents Wadi El Natrun which is one of the important areas for land reclamation and developmental projects. Present study represents one of the initial attempts to use the MEDALUS model for desertification assessment in the desert extension of El-Beheira Governorate. The MEDALUS is a distinguished model for evaluating the desertification phenomena in arid and semi-arid regions on basis of laboratory analyses, spatial data and various GIS thematic layers. To achieve this, several inputs criteria covering four different indicators (i.e., management quality, vegetation quality soil quality, and climate quality) were used. The model presented optimistic results showing that most of the study area (76 \%) was covered by the low sensitive areas to desertification. A portion of the low sensitive areas are not yet cultivated and are characterized by high soil quality index. It can be concluded that the desert extension of El-Beheira Governorate (i.e. Wadi El Rayan) is one of the areas that possess valuable land resources which should be considered for future land reclamation projects. Similar international studies are recommended to be achieved with the use of multi-criteria GIS modeling (i.e. MEDALUS) which considered all relevant factors in the form of thematic layers for easier implementation and assessments.

\section{REFERENCES}

Abd El-Ghani M.M., Hamdy R.S. and Hamed A.B. 2015. Habitat Diversity and Floristic Analysis of Wadi El-Natrun Depression, Western Desert, Egypt. Phytologia Balcanica; 21(3), 351-366.

Adger W.N., Benjaminsen T.A., Brown K. and Svarstad H. (Ed.) 2000. Advancing a Political Ecology of Global Environmental Discourse.
Centre of Social and Economic Research on the Global Environment, Univ., of East Anglia, London.

Basso F., Bove E., Dumontet A., Ferrara A., Pisante M., Quaranta G. and Taberner M. 2000. Evaluating environmental sensitivity at the basin scale through the use of geographic information systems and remotely sensed data: an example covering the Agri basin (Southern Italy). Catena; 40, 19-35.

El-Maghraby M.M. 1990. Geographical and hydrological studies of Sadat City, Egypt. M.Sc. Thesis, Fac. Sci., Alexandria Univ.,

Lee E.J., Piao D., Song C., Kim J., Lim C.H., Kim E., Moon J., Kafatos M., Lamchin M., Jeon S. W. and Lee W.K. 2019. Assessing environmentally sensitive land to desertification using MEDALUS method in Mongolia. Forest Sci. and Technology 15(4), 210-220.

Gad A. and Shalaby A. 2010. Assessment and mapping of desertification sensitivity using Remote Sensing and GIS Case study: Inland Sinai and Eastern Desert Wadies. US-Egypt Workshop on Space Technology and Geo-information for Sustainable Development, Cairo, Egypt, pp. 14-17.

Gad A. 2020. Qualitative and Quantitative Assessment of Land Degradation and Desertification in Egypt Based on Satellite Remote Sensing: Urbanization, Salinization and Wind Erosion. Environmental Remote Sensing in Egypt. Springer Geophysics. Springer, Cham.

Herrmann S.M. and Hutchinson C.F. 2005. The changing contexts of the desertification debate. J. Arid Environ; 63, 538-555.

Kosmas C., Ferrara A., Briasouli H. and Imeson A. 1999. Methodology for mapping environmentally sensitive areas (ESAs) to desertification. Mediterranean Desertification and Land Use (MEDALUS), European Union 18882, 31-47. ISBN 92-828-6349-2

Kosmas C., Kirkby M. and Geeson N. 1999. The MEDALUS project: Mediterranean desertification and land use. Manual on Key Indicators of Desertification and Mapping Environmentally Sensitive Areas to Desertification European Commission, Project ENV4 CT 950119 (EUR 18882).

Lamchin M., Lee J.Y., Lee W.K., Lee E.J., Kim M., Lim C.H., Choi H.A. and Kim S.R. 2016. Assessment of land cover change and desertification using remote sensing technology in a local region of Mongolia. Adv. Space Res; 57, 64-77. 
Lamqadem A.L., Pradhan B., Saber H., and Rahimi A. 2018. Desertification Sensitivity Analysis Using MEDALUS Model and GIS: A Case Study of the Oases of Middle Draa Valley, Morocco. Sensors; 18, 22-30.

Le Bissonnais Y. 1996. Aggregate stability and assessment of crustability and erodibility: $\mathbf{1}$. Theory and methodology. Eur. J. Soil Sci., 47, 425-437.

Luca S. and Sofia B. 2011. Land sensitivity to desertification across Italy: Past, present, and future. Appl. Geogr; 31, 223-231.

Mohamed E.S. 2013. Spatial Assessment of Desertification in North Sinai Using Modified MEDLAUS Model. Arabian J. Geosciences; 6, 4647-4659.

Thomas D.S.G. 1997. Science and desertification debate. J. Arid Environ, 37, 599-608.
Schoeneberge P.J. and Wysock A.I. 2005. Hydrology of soils and deep regolith: a nexus between soil geography, ecosystems and land management. Geoderma; 126 (1-2), 117-128.

UNCCD (United Nations Convention for Combating Desertification) 1994. United Nations Convention to Combat Desertification - The Text of Article. (Accessed May 7, 2020, at http://www.unccd.int/Lists/SiteDocumentLibrary/ conventionText/conv-eng.pdf).

UNCCD (United Nations Convention for Combating Desertification) 2000. Assessment of the Status of Land Degradation in Arid, Semi-arid and Dry Sub-humid Areas. United Nations Convention to Combat Desertification, Bonn Germany.

Wulder M.A., White J.C., Goward S.N., Masek J.G., Irons J.R., Herold M., Cohen W.B. and Loveland T.R. 2008. Issues and opportunities for land cover monitoring. Remote Sensing of Environment; 112, 955-969. 


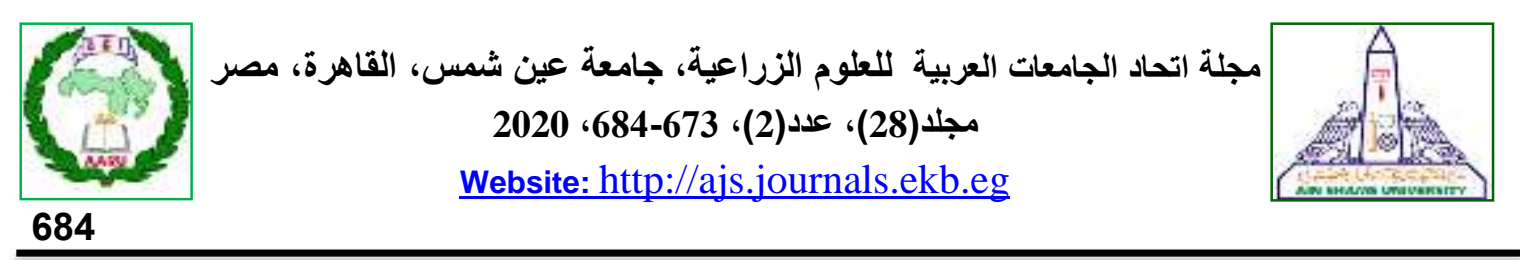

التقييم والتحليل المكاني لحساسية التصحر في وادي النطرون، شمال غرب مصر MEDLAUS بإستخدام نموذج

[50]

$$
\begin{aligned}
& \text { هاى نور الاين" }{ }^{*} \text { - عبد العزيز شتا2 - عادل شلبى1 - محمد سيف عبد الواحد2 - } \\
& \text { محمد زكى الشناوى } 3 \\
& \text { 1- قسم استخدامات الأراضى - الهيئة القومية للاستشعار من البعد وعلوم الفضاء - مصر } \\
& \text { 2- قسم الآراضي - كلية الزراعة - جامعة عين شمس - ص.ب 68- حدائق شبرا } 11241 \text { - القاهرة - مصر } \\
& \text { 3- قسم البساتين - كلية الزراعة - جامعة عين شمس - ص.ب 68- حدائق شبرا } 11241 \text { - القاهرة - مصر }
\end{aligned}
$$

*Corresponding author: hoda.noureldin2008@gmail.com

Received 21 March, $2020 \quad$ Accepted 16 August, 2020

النتائج أن 10.4\% من منطقة وادي النطرون تعتبر

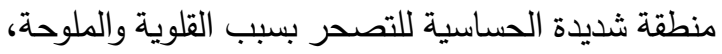

بينما تحتل درجة الحساسية المتوسطة للتصحر

10.93 من منطقة الدراسة. تشغل درجة الحساسية

المنخفضة مساحة قدرها 76.3\% ونتميز تلكانك المنطقة بجودة التربة العالية حيث تمثل أحد مناطق التتمية

الجديدة الواعدة التي لم تتأثر بعد بعوامل التصحر ملثل

الكلمات المفتاحية: التصحر، MEDALUS، وادى

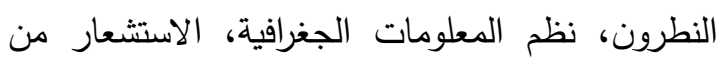
البعد

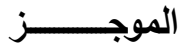

تؤدى ظاهرة التصحر الى انخفاض إنتاجية التربة

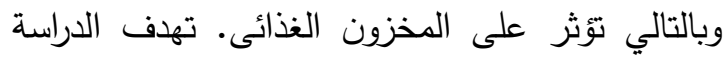
الحالية الى دمج بيانات الاستثعار من البعد ونظم

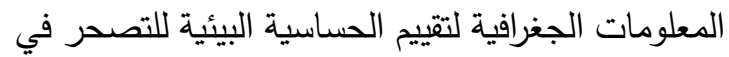

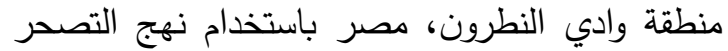
واستخدام الأراضي في منطقة البحر الأبيض المتوسط المان (MEDALUS) تشمل الوصف الموفورلوجى للقطاعات الممثلة وتحليل

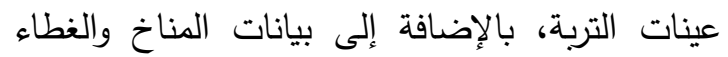
النباتي وبيانات الإدارة لتقييم حساسية التصحر ـ أظهرت 